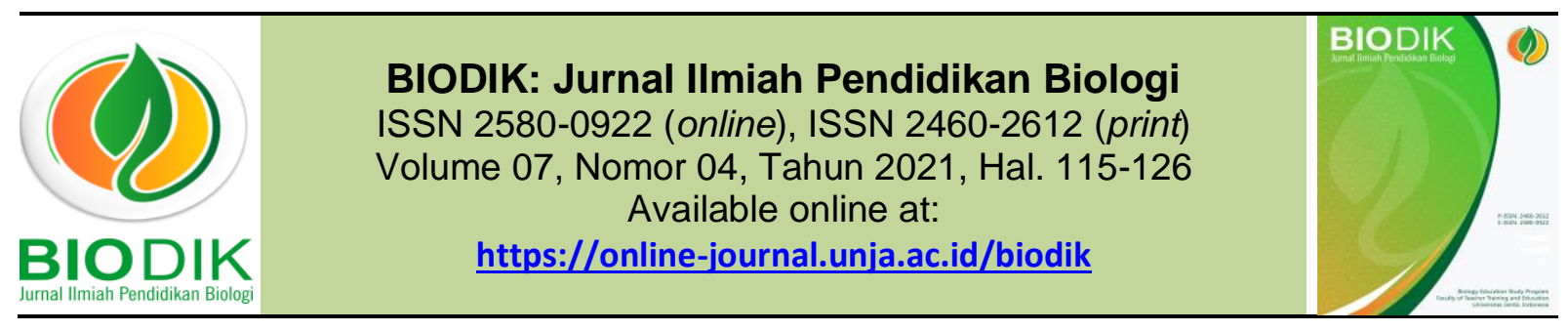

Research Article

\title{
Analisis Korelasi Sikap Ilmiah dan Hasil Belajar Biologi
}

\section{(Analysis Correlation of Scientific Attitude and Biological Learning Outcomes)}

\author{
Muhammad Nasrul Mustain*, Bonita Hirza, Rusdy A. Siroj \\ Program Pascarjana Pendidikan Biologi, \\ Fakultas Keguruan dan IImu Pendidikan, Universitas Muhammadiyah Palembang \\ JI. Jendral Ahmad Yani, Kelurahan 13 Ulu, Kecamatan Seberang Ulu II, Kota Palembang, Sumatera Selatan 30263 \\ ${ }^{*}$ Corresponding authors: nasrulmustain1@gmail.com
}

\begin{tabular}{|c|c|}
\hline Informasi Artikel & ABSTRACT \\
\hline \multirow{8}{*}{$\begin{array}{l}\text { Submit: } 18-08-2021 \\
\text { Diterima: } 01-12-2021 \\
\text { Dipublikasikan: } 27-12-2021\end{array}$} & This study intends to provide information: (1) the level of scientific attitude \\
\hline & ability of Biology students (2) the level of learning outcomes of Biology lessons \\
\hline & $\begin{array}{l}\text { (3) see the relationship between scientific attitudes and learning outcomes in } \\
\text { Biology The tvpe of research was correlation research. The research }\end{array}$ \\
\hline & $\begin{array}{l}\text { population was all high school students in Ogan Komering ilir district, which is } \\
\text { taken } 30 \% \text { of the sample area so that } 5 \text { districts represent the population. The }\end{array}$ \\
\hline & $\begin{array}{l}\text { sample technique used is perposive sampling with a total of } 1827 \text { students and } \\
\text { the instruments used are scientific attitude questionnaires and odd semester } \\
\text { test scores for the 2020/2021 school year. The results showed ((1) students' }\end{array}$ \\
\hline & \\
\hline & $\begin{array}{l}82 \text { in the medium category, (3) There was a significant relationship between } \\
\text { scientific attitudes and cognitive learning outcomes in Biology lessons with a } \\
\text { relationship level of } 0.655 \text { including a "strong" correlation. }\end{array}$ \\
\hline & Key words: Scientific Attitude, Learning Outcomes \\
\hline Penerbit & ABSTRAK \\
\hline \multirow{11}{*}{$\begin{array}{l}\text { Program Studi Pendidikan Biologi } \\
\text { FKIP Universitas Jambi, } \\
\text { Jambi- Indonesia }\end{array}$} & Penelitian ini bermaksud untuk memberikan informasi: (1) tingkat kemampuan \\
\hline & sikap ilmiah siswa pelajaran Biologi (2) tingkat kemampuan hasil belajar \\
\hline & $\begin{array}{l}\text { pelajaran Biologi (3) melihat hubungan antara sikap ilmiah dan hasil belajar } \\
\text { pelaiaran Biologi. Jenis penelitian ini adalah penelitian korelasi. Populasi }\end{array}$ \\
\hline & penelitian adalah seluruh siswa Sekolah Menengah Atas di kabupaten Ogan \\
\hline & $\begin{array}{l}\text { Komering ilir, yang diambil } 30 \% \text { dari sampel wilayah sehingga } 5 \text { kabupaten } \\
\text { mewakili populasi. Tekhnik sampel yang digunakan adalah perposive sampling }\end{array}$ \\
\hline & $\begin{array}{l}\text { dengan total siswa adalah } 1827 \text { siswa dan instrumen yang digunakan adalah } \\
\text { kuisioner sikap ilmiah dan nilai ulangan semester ganjil tahun ajaran }\end{array}$ \\
\hline & $\begin{array}{l}\text { 2020/2021. Hasil penelitian didapatkan bahwa; (1) sikap ilmiah siswa } \\
\text { memperoleh skor rata-rata sebesar } 89 \text { dengan kategori sedang, (2) Hasil }\end{array}$ \\
\hline & belajar Kognitif siswa pelajaran Biologi memperoleh skor rata-rata sebesar 82 \\
\hline & dengan kategori sedang, (3) Terdapat hubungan signifikan antara sikap ilmiah \\
\hline & $\begin{array}{l}\text { dengan hasil belajar Kognitif pelajaran Biologi dengan tingkatan hubungan } \\
\text { sebesar } 0,655 \text { termasuk dalam korelasi "kuat". }\end{array}$ \\
\hline & Kata kunci: Sikap IImiah, Hasil Belajar \\
\hline
\end{tabular}

This BIODIK : Jurnal IImiah Pendidikan Biologi is licensed under a CC BY-NC-SA (Creative Commons Attribution-ShareAlike 4.0 International License) 


\section{PENDAHULUAN}

Pada hakikatnya pembelajaran Biologi tidak hanya menekankan pada pengetahuan, tetapi juga mengedepankan sikap, meningkatkan keterampilan siswa yang dapat diterapkan dalam kehidupan nyata. Lebih lanjut pembelajaran Biologi adalah pembelajaran yang semua aspeknya didasarkan pada proses ilmiah yang mengkaji pertanyaan terkait fenomena antara makhluk hidup dan lingkungan dari tingkat organisasi kehidupan serta hubungannya dengan lingkungan (Khairunnisa, Ita, \& Istiqamah, 2019). Keberhasilan proses pembelajaran Biologi tidak lepas dari perkembangan sikap, karena sikap yang dibangun melalui pembelajaran dapat memberikan dampak positif bagi siswa. Sikap yang muncul pada diri siswa saat belajar adalah perasaan suka atau tidak suka terhadap mata pelajaran tersebut. Perasaan ini dikenal dalam Biologi sebagai sikap sikap ilmiah (Science Atitude) dan tergolong (behavior response) yang muncul dalam bentuk tingkah laku (Dewi \& Rosana, 2017).

Sikap ilmiah termasuk dalam ranah afektif, menyangkut kebiasaan sesorang dalam melakukan kegiatan ilmiah. Sikap ilmiah adalah keterampilan yang digunakan untuk melakukan pembelajaran dengan menggunakan data yang akurat (fakta) daripada data yang belum diverifikasi. Pola pikir ilmiah ini merupakan bentuk kecerdasan yang dimiliki siswa dalam melakukan kegiatan pembelajaran sehingga dapat memberikan pengaruh terhadap hasil belajar (Jhon \& Ademola, 2014). Sehingga sikap ilmiah menjadi salah satu faktor penentu keberhasilan belajar siswa, dengan kemampuan sikap ilmiah yang baik menimbulkan aktivitas kegiatan belajar yang lebih baik pula dan menyebabkan siswa lebih tekun serta aktif dalam belajar, dengan kegiatan tersebut siswa akan mendapatkan hasil belajar yang lebih baik daripada siswa dengan kemampuan sikap ilmiah yang buruk (Putri, Idrus, \& Yennita, 2017).

Sikap ilmiah dapat terbentuk dengan melatih kebiasaan peserta didik untuk menentukan sikap dalam pembelajaran secara ilmiah, dengan memiliki sikap ilmiah berikut ini: 1) keingintahuan tinggi, 2) kritis dalam menghadapi informasi, 3) terbuka dalam menanggapi pendapat orang lain, 4) objektif dalam tindakan, 5) menghargai ciptaan teman, 6) berani menampilkan gagasan yang benar, dan 7) memiliki pandangan yang lebih maju (Haryaka \& Haslidia, 2019). Sedangkan pendapat lain menyatakan bahwa; sikap ilmiah terdiri dari 1) sikap keingintahuan; 2) kejujuran 3) objektif; 4) ketekunan' 5) teliti; 6) terbuka; 7) kritis; 8) tanggung jawab. Dengan menanamkan keterampilan sikap ilmiah, siswa menjadi lebih terbiasa dengan sikap belajar yang positif, sehingga mendorong siswa untuk untuk mencapai hasil belajar yang baik. Oleh karena itu perlu suatu perhatian pendidik untuk menilai sikap ilmiah siswa sebagai sarana untuk melatih kemampuan siswa dalam mencapai keberhasilan hasil belajar dalam pelajaran Biologi (Supardi, Istiyono, \& Setilalaksana, 2019).

Dunia pendidikan saat pandemi Covid-19 bertransformasi dari kegiatan pembelajaran secara tatap muka beralih menjadi pembelajaran jarak jauh dengan menggunakan jaringan, kewajiban seorang guru tidak terlepas dari proses penilaian sebagai alat evaluasi untuk mencapai ketuntasan pembelajaran, sehingga proses penilaian menjadi lebih sulit salah satunya adalah penilaian sikap yang seharusnya dilakukan secara langsung sehingga beralih menggunakan penilaian dalam jaringan, salah satu cara sikap ilmiah dapat diukur menggunakan instrumen yang merujuk kepada item pernyataan disusun sesuai dengan indikator sikap ilmiah sebagai berikut: 1) sikap keingintahuan; 2) kejujuran 3) objektif; 4) ketekunan' 5) teliti; 6) terbuka; 7) kritis; 8) tanggung jawab, dan instrumen dibuat menggunakan media Google Form.

Berdasarkan hasil wawancara peneliti pada tanggal 27 Mei 2020 dengan guru pelajaran Biologi di SMA Kabupaten Ogan Komering Ilir, didapat informasi bahwa: 1) guru belum pernah 
melakukan penilaian keterampilan sikap ilmiah dalam proses pembelajaran, guru hanya melakukan penilaian pengetahuan saja; 2) guru masih kesulitan dalam melakukan penilaian sikap ilmiah karena kurangnya pemahaman dalam penilaian sikap peserta didik; 3) hasil data PAMER UN tahun 2018/2019 di Provinsi Sumatera Selatan SMA didapatkan hasil Ujian Nasional SMA di Kabupaten Ogan Komering Ilir berada diperingkat 12 dari 17 Kabupaten/Kota dengan hasil rata-rata nilai seluruh pelajaran sebesar 43,76, sedangkan pelajaran Biologi nilai Ujian Nasional SMA dikabupaten Ogan Komering llir berada diperingkat 9 dengan rerata nilai sebesar 44.69. Sehingga perlu adanya upaya dalam perbaikan terhadap peningkatan kemampuan pengetahuan siswa untuk mencapai keberhasilan belajar.

Perlunya perhatian seorang pendidik dalam mengukur sikap ilmiah peserta didik, karena karena dengan mengukur sikap ilmiah pendidik dapat mengetahui kemampuan sikap ilmiah peserta didik dan memudahkan dalam menentukan strategi pembelajaran yang dapat memupuk sikap ilmiah siswa. Karena sikap ilmiah juga dapat memotivasi kegiatan belajar siswa (Sihombing, 2016). Melihat urgensi yang diuraikan di atas, peneliti perlunya mengukur sikap ilmiah dan hasil belajar Biologi siswa SMA di Kabupaten Ogan Komering llir.

\section{METODE PENELITIAN}

Penelitian dilaksanakan pada tanggal 23 November 2020 sampai 30 Desember 2020. Jenis penelitian merupakan penelitian korelasi sederhana, penelitian ini bertujuan untuk melihat korelasi antara dua variabel yaitu antara sikap ilmiah dan hasil belajar Biologi. Populasi adalah seluruh SMA yang berada di Kabupaten Ogan Komering llir yang tersebar di 18 Kecamatan/Kota. Namun peneliti hanya mengambil sampel $30 \%$ dari populasi ditingkat kecamatan. Sehingga jumlah sampelnya adalah $18 \times 30 \%=5,4$. Jadi sempel yang mewakili dari populasi adalah 5 kecamatan.

Penentuan sampel wilayah dipilih menggunakan teknik cluster sampling sehingga didapatkan Kecamatan Tulung Selapan, Pampangan, Pangkalan Lampam, Sirau Pulau Padang dan Jejawi yang mewakili populasi, jumlah sekolah SMA dari 5 kecamatan tersebut adalah 7 SMA (swasta/negeri) yang terakreditasi. Sampel diambil seluruhnya dari 7 SMA tersebut yakni: kelas X IPA sampai XII IPA sehingga didapatkan jumlah 1827 siswa untuk mewakili populasi siswa SMA Se-Kabupaten Ogan Komering ilir.

Instrumen penilitian yang digunakan adalah Kuisioner sikap ilmiah sebagai alat mengukur kemampuan sikap ilmiah siswa, dengan bantuan Google Form dan nilai hasil belajar siswa diperoleh dari nilai ulangan semester ganjil pelajaran Biologi tahun ajaran 2020/2021. Angket sikap disusun dengan mengacu pada indikator sikap ilmiah yang dikembangkan oleh Supardi, Istiyono dan Setialaksana (2019:3), indikator sikap ilmiah terdiri dari (1) sikap keingintahuan; (2) kejujuran (3) objektif; (4) ketekunan' (5) teliti; (6) terbuka; (7) kritis; (8) tanggung jawab. Kuisioner telah melewati validasi pakar dengan 2 orang dosen sebagai validator dan selanjutnya angket di uji coba terhadap responden, untuk melihat validitas dan reliabelitas angket. uji validitas dihitung dengan taraf signifikasi sebesar $5 \%$, dimana $d f=32-2=30$ sehingga didapatkan ( $\left.r_{\text {tabel }}=0,361\right)$. Data diasumsikan valid bila $\mathrm{r}_{\text {hitung }}$ $>r_{\text {tabel }}(0,361)$. Hasil output uji validitas menggunakan SPSS for windows versi 26.0, terdapat 29 item diasumsikan valid dan 3 item diasumsikan tidak valid, sedangkan hasil uji reabilitas dari seluruh 32 item pernyataan diasumsikan reliabel, karena nilai $\alpha>0.60$, sehingga instrumen yang digunakan pada penelitian ini berjumlah 29 item pernyataan yang disusun menggunakan penskoran skala likert . 
BIODIK: Jurnal IImiah Pendidikan Biologi

Vol. 07, No. 04 (2021), Hal. $115-126$

Tabel 1. Pedoman Penskoran Angket Sikap IImiah

\begin{tabular}{ccccc}
\hline No & Pilihan Item & Keterangan & \multicolumn{2}{c}{ Skor Item Pertanyaan } \\
\cline { 3 - 5 } & & & Positif & Negatif \\
\hline 1 & SS & (Sangat sering ) & 4 & 1 \\
2 & S & (Sering) & 3 & 2 \\
3 & J & (Jarang) & 2 & 3 \\
4 & TP & (Tidak Pernah) & 1 & 4 \\
\hline
\end{tabular}

Selanjutnya hasil perolehan data skor angket sikap ilmiah dapat dianalisis secara deskriptif untuk mengetahui kategori kecenderungan sikap ilmiah siswa.

Tabel 2. Rumus Rentang Kategori Slkap IImiah

\begin{tabular}{cc}
\hline Rumus & Kriteria \\
\hline$M+1,5 S D<x$ & Sangat Tinggi \\
$M+0,5 S D<x \leq M+1,5 S D$ & Tinggi \\
$M-0,5 S D<x \leq M+0,5 S D$ & Sedang \\
$M-1,5 S D<x \leq M-0,5 S D$ & Rendah \\
$x \leq M-1,5 S D$ & Sangat Rendah \\
\hline
\end{tabular}

(Sumber: Azwar, 2012)

Keterangan:

Nilai rata-rata $\quad=M$

Standar deviasi $\quad=$ SD

Berdasarkan hasil perhitungan dari data skor jawaban sikap ilmiah siswa, setelah dilakukan penelitian, maka dapat dihitung pedoman kriteria penskoran menggunakan rumus di atas, sehingga dapat diperoleh rentang nilai interval sikap ilmiah berdasarkan lima kategori.

$\begin{array}{ll}M & =89 \\ S D & =12 \\ M-1,5 S D & =71 \\ M-0,5 S D & =83 \\ M+0,5 S D & =95 \\ M+1,5 S D & =107\end{array}$

Tabel 3. Pedoman Kategori Sikap IImiah

\begin{tabular}{ccc}
\hline Rumus & Kriteria & Nilai Interval \\
\hline$M+1,5 S D<x$ & Sangat Tinggi & $X>107$ \\
$M+0,5 S D<x \leq M+1,5 S D$ & Tinggi & $95<X \leq 107$ \\
$M-0,5 S D<x \leq M+0,5 S D$ & Sedang & $83<X \leq 95$ \\
$M-1,5 S D<x \leq M-0,5 S D$ & Rendah & $71<X \leq 83$ \\
$x \leq M-1,5 S D$ & Sangat Rendah & $X<71$ \\
\hline
\end{tabular}

Selanjutnya, hasil jawaban angket peserta didik dianalisis untuk mengetahui persentase ketercapaian sikap ilmiah pada setiap indikator, karena jumlah item tidak merata maka digunakanlah rumus persentase untuk melihat kemunculan ketercapaian sikap ilmiah. 


$$
\begin{gathered}
\text { BIODIK: Jurnal Ilmiah Pendidikan Biologi } \\
\text { Vol. 07, No. } 04 \text { (2021), Hal. } 115-126 \\
\mathrm{~N}=\frac{\text { Skor total perolehan siswa setiap item }}{\text { Skor maksimum }} \times 100
\end{gathered}
$$

Keterangan :

$N=$ sikap ilmiah siswa

Berdasarkan perhitungan persentase dengan rumus di atas didapatkan hasil persentase setiap indikator sikap ilmiah, selanjutnya hasil persentase tersebut dapat dikategorikan berdasarkan pedoman tingkat ketercapaian indikator sikap ilmiah siswa.

Tabel 4. Pedoman Tingkat Ketercapaian Setiap Indikator Sikap Ilmiah

\begin{tabular}{cc}
\hline Persentase & Kategori \\
\hline $90 \%-100 \%$ & Sangat Tinggi \\
$80 \%-89 \%$ & Tinggi \\
$70 \%-79 \%$ & Cukup Tinggi \\
$60 \%-69 \%$ & Rendah \\
$<59 \%$ & Sangat Rendah \\
\hline
\end{tabular}

(Sumber: Arifin, 2014)

Sedangkan perhitungan penskoran hasil belajar Biologi menggunakan rumus yang disajikan dibawah ini untuk mendapatkan nilai interval berdasarkan lima kategori hasil belajar.

Tabel 5. Rumus Rentang Kategori Hasil Belajar

\begin{tabular}{cc}
\hline Rumus & Kriteria \\
\hline$M+1,5 S D<x$ & Sangat Tinggi \\
$M+0,5 S D<x \leq M+1,5 S D$ & Tinggi \\
$M-0,5 S D<x \leq M+0,5 S D$ & Sedang \\
$M-1,5 S D<x \leq M-0,5 S D$ & Rendah \\
$x \leq M-1,5 S D$ & Sangat Rendah \\
\hline
\end{tabular}

(Sumber: Azwar, 2012)

Keterangan:

Nilai rata-rata $\quad=\mathrm{M}$

Standar deviasi $\quad=$ SD

Hasil perhitungan nilai hasil belajar Biologi siswa, maka dapat dihitung menggunakan pedoman kriteria penskoran menggunakan rumus di atas, sehingga dapat diperoleh rentang nilai interval hasil belajar Biologi menjadi lima kategori.

$\begin{array}{ll}M & =82 \\ S D & =6 \\ M-1,5 S D & =79 \\ M-0,5 S D & =85 \\ M+1,5 S D & =90\end{array}$


Tabel 6. Pedoman Kategori Hasil Belajar

\begin{tabular}{ccc}
\hline Rumus & Kriteria & Nilai Interval \\
\hline$M+1,5 S D<x$ & Sangat Tinggi & $X>90$ \\
$M+0,5 S D<x \leq M+1,5 S D$ & Tinggi & $85<X \leq 90$ \\
$M-0,5 S D<x \leq M+0,5 S D$ & Sedang & $79<X \leq 85$ \\
$M-1,5 S D<x \leq M-0,5 S D$ & Rendah & $73<X \leq 79$ \\
$x \leq M-1,5 S D$ & Sangat Rendah & $X<73$ \\
\hline
\end{tabular}

Kemudian data dianalisis untuk melihat hubungan antar variabel dengan uji korelasi sederhana menggunakan SPSS for windows versi 26.0, sebelum uji korelasi product moment terdapat uji prasyarat meliputi normalitas dan linearitas. Karena kedua data yaitu sikap ilmiah dan hasil belajar tidak berdistribusi normal, maka uji korelasi menggunakan analisis secara non-parametrik menggunakan uji spearman's rho. Selanjutnya hasil perhitungan korelasi dengan uji spearman's tho dapat dikategorikan tingkat korelasi atau kekuatan hubungan disajikan pada tabel 7 .

Tabel 7. Tingkat Kekuatan Hubungan

\begin{tabular}{cc}
\hline Interval Koefisien $(r)$ & Tingkatan Hubungan \\
\hline $0,800-0,100$ & Sangat Kuat \\
\hline $0,600-0,799$ & Kuat \\
\hline $0,400-0,599$ & Cukup Kuat \\
\hline $0,200-0,399$ & Lemah \\
\hline $0,000-0,199$ & Sangat Lemah \\
\hline
\end{tabular}

Adapun pengambilan keputusan diambil berdasarkan nilai propabilitas $\alpha=0.05$, dan hasil pembacaannya yaitu; apabila nilai (sig.) $<\alpha$ ), maka $\mathrm{H}_{0}$ ditolak dan $\mathrm{H}_{a}$ diterima dan apabila (sig.) $>\alpha$, maka $\mathrm{H}_{0}$ diterima dan $\mathrm{H}_{\mathrm{a}}$ ditolak.

\section{HASIL PENELITIAN DAN PEMBAHASAN}

Hasil data penelitian telah didapatkan informasi mengenai kemampuan sikap ilmiah dan kemampuan hasil belajar siswa pada aspek pengetahuan di SMA kabupaten Ogan Komering ilir. Berdasarkan hasil tanggapan responden dari 29 pernyataan dalam angket sikap ilmiah yang telah dianalisis secara deskripsi statistik, sehingga dapat diperoleh rata-rata skor sikap ilmiah.

Tabel 8. Deskripsi Statistik Sikap IImiah

\begin{tabular}{|c|c|c|c|c|c|c|}
\hline & \multirow{2}{*}{ Range } & \multirow{2}{*}{$\begin{array}{c}\text { Skor } \\
\text { Terendah }\end{array}$} & \multirow{2}{*}{$\begin{array}{c}\text { Skor } \\
\text { Tertinggi }\end{array}$} & \multicolumn{2}{|c|}{ Rata-Rata } & \multirow{2}{*}{$\begin{array}{c}\text { SD } \\
\text { Statistik }\end{array}$} \\
\hline & & & & Statistik & Standar Error & \\
\hline Sikap IImiah & 56,00 & 60,00 & 116,00 & 89 & 0,37274 & 12,15274 \\
\hline Responden & & & & 1063 & & \\
\hline
\end{tabular}

Hasil perhitungan di atas menjelaskan bahwa dari jumlah siswa sebanyak 1063 terdapat siswa yang memiliki skor maksimal 116 dan tidak ada siswa yang memperoleh skor minimal 29, karena perolehan skor siswa terendah sebesar 60 . Hasil perhitungan rata-rata skor sikap ilmiah siswa SMA di Kabupaten Ogan Komering llir memperoleh skor sebesar 89 dengan tingkat kategori tergolong sedang. 
Selanjutnya data sikap ilmiah siswa dihitung untuk melihat distribusi frekuensi kecenderungan sikap ilmiah menjadi lima kriteria. Pedoman perhitungan dapat dilihat pada Tabel 3, adapun gambaran mengenai distribusi frekuensi sikap ilmiah siswa di SMA sekabupaten Ogan Komering llir.

Tabel 9. Distribusi Frekuensi Sikap IImiah

\begin{tabular}{cccc}
\hline Kriteria & Interval & Frekuensi & Persentase (\%) \\
\hline Sangat Tinggi & $\mathrm{X}>107$ & 82 & 7,71 \\
\hline Tinggi & $95<\mathrm{X} \leq 107$ & 235 & 22,11 \\
\hline Sedang & $83<\mathrm{X} \leq 95$ & 379 & 35,65 \\
\hline Rendah & $71<\mathrm{X} \leq 83$ & 309 & 29,07 \\
\hline Sangat Rendah & $\mathrm{X}<71$ & 57 & 5.36 \\
\hline & & 1063 & 100.0 \\
\hline
\end{tabular}

Data distribusi frekuensi sikap ilmiah pada Tabel 4 di atas menjelaskan bahwa siswa SMA di Kabupaten Ogan Komering Ilir memiliki persentase frekuensi tertinggi pada kriteria sedang, dengan persentase frekuensi sebesar $35,66 \%$ yang berjumlah 379 siswa, sedangkan kriteria persentase frekuensi terendah yaitu berada dikriteria sangat tinggi dengan persentase frekuensi sebesar $7.71 \%$ dengan jumlah 82 siswa. Selanjutnya berdasarkan hasil jawaban siswa dapat dianalisis ketercapaian sikap ilmiah untuk masing-masing indikator sikap ilmiah.

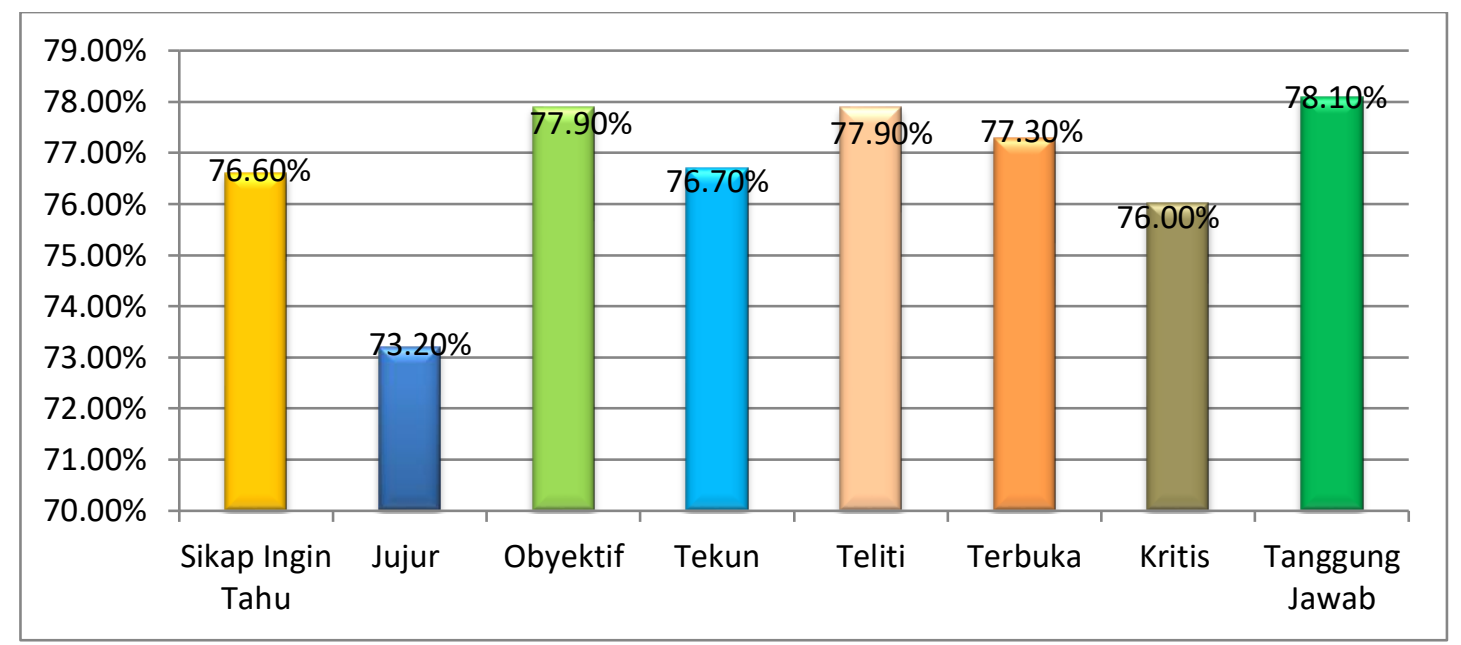

Gambar 1. Persentase Ketercapaian pada Setiap Indikator Sikap IImiah Siswa

Berdasarkan data hasil persentase ketercapaian siswa SMA di Kabupaten Ogan Komering llir pada setiap indikator sikap ilmiah menunjukkan persentase ketercapaian tertinggi pada indikator tanggung jawab dengan hasil persentase sebesar $78,10 \%$, sedangkan persentase ketercapaian terendah berada pada indikator jujur dengan persentase sebesar $73,20 \%$. Berdasarkan pedoman kriteria ketercapaian pada semua indikator sikap ilmiah dapat dikategorikan berdasarkan tingkatan kriteria, hasil semua indikator sikap ilmiah berada pada rentang kriteria yang sama yaitu kriteria cukup tinggi, pedoman kriteria persentase ketercapaian sikap ilmiah pada setiap indikator dapat dilihat pada Tabel 4. Selanjutnya data hasil belajar Biologi dilakukan analisis deskripsi statistic untuk melihat ratarata skor hasil belajar Biologi siswa di SMA sekabupaten Ogan Komering Ilir. 
Tabel 10. Deskripsi Statistik Hasil Belajar Kognitif Siswa

\begin{tabular}{|c|c|c|c|c|c|c|}
\hline & \multirow{2}{*}{ Range } & \multirow{2}{*}{$\begin{array}{c}\text { Skor } \\
\text { Terendah }\end{array}$} & \multirow{2}{*}{$\begin{array}{c}\text { Skor } \\
\text { Tertinggi }\end{array}$} & \multicolumn{2}{|c|}{ Mean } & \multirow{2}{*}{$\frac{\text { SD }}{\text { Statistik }}$} \\
\hline & & & & Statistik & Standar Error & \\
\hline Hasil Belajar & 32,00 & 60,00 & 92,00 & 82 & 0,17091 & 5,57228 \\
\hline Responden & & & 106 & & & \\
\hline
\end{tabular}

Hasil data di atas menjelaskan bahwa dari jumlah siswa sebesar 1063 memperoleh hasil Belajar Biologi dengan skor terendah 60 dan skor tertinggi sebesar 92. Sehingga dapat diketahui siswa tidak ada yang memperoleh nilai maksimal 100 , namun jauh dari nilai minimal 50 . hasil rata-rata skor sikap ilmiah siswa SMA di kabupaten Ogan Komering llir memperoleh skor rata-rata sebesar 82 dengan tingkat kriteria tergolong sedang. selanjutnya data dihitung untuk melihat kecenderungan hasil belajar Biologi menjadi lima kategori. Adapun gambaran hasil belajar Biologi siswa SMA sekabupaten Ogan Komering llir dapat dilihat pada Tabel 7.

Tabel 11. Distribusi Frekuensi Hasil Belajar Biologi

\begin{tabular}{ccc}
\hline Kriteria & Frekeunsi & Persentase $(\%)$ \\
\hline Sangat Tinggi & 3 & $0,28 \%$ \\
Tinggi & 230 & $21,64 \%$ \\
Sedang & 563 & $52,96 \%$ \\
Rendah & 168 & $15,80 \%$ \\
Sangat Rendah & 99 & $9,31 \%$ \\
\hline Total & 1063 & $100 \%$ \\
\hline
\end{tabular}

Data di atas menjelaskan bahwa banyak siswa yang cenderung memiliki hasil belajar berada dikriteria sedang dengan hasil persentase distribusi frekuensi sebesar $52,96 \%$ berjumlah 563 siswa sedangkan persentase distribusi frekuensi terendah sebesar $0,28 \%$ berada dikriteria sangat tinggi dan hasil rata-rata dari nilai hasil belajar aspek pengetahuan pelajaran Biologi di SMA sekabupaten Ogan Komering llir diperoleh nilai memperoleh 82 direntang kriteria sedang. Selanjutnya dari kedua data yaitu sikap ilmiah dan hasil belajar Biologi dilakukan uji prasyarat dengan uji Normalitas data. Sebagai syarat sebelum dilakukan uji korelasi.

Tabel 12. Uji Normalitas Data Sikap IImiah dan Hasil Belajar

\begin{tabular}{cccc}
\hline \multicolumn{5}{c}{ Kolmogorov Smirnov } & \\
\hline Variabel & Statistik & df & Signifikan \\
\hline sikap ilmaih & 0,047 & 1063 & 0,000 \\
\hline hasil belajar & 0,121 & 1063 & 0,000 \\
\hline
\end{tabular}

Berdasarkan tabel tersebut didapatkan nilai signifikan sebesar $(0.000<0.05)$, diartikan bahwa data tersebut tidak normal. Hasil pengujian yang digunakan adalah uji Kolmogorov Smirnov yang dibantu oleh aplikasi SPSS for windows versi 26. Karena kedua data tersebut tidak memenuhi uji prasyarat secara parametrik. Jadi untuk melihat korelasi antara kedua variabel sikap ilmiah dan variabel hasil belajar dilakukan uji hipotesis secara non-parametrik menggunakan uji Spearmen's rho. 
BIODIK: Jurnal IImiah Pendidikan Biologi

Vol. 07, No. 04 (2021), Hal. 115 - 126

Tabel 13. Uji Spearman's rho

\begin{tabular}{|c|c|c|c|}
\hline & Spearmen's rho & Sikap IImiah & Hasil Belajar \\
\hline \multirow{3}{*}{ Sikap IImiah } & Koefisien Korelasi & 1.000 & $0,655^{* *}$ \\
\hline & Sig. (2-tailed) & . & 0,000 \\
\hline & $\mathrm{N}$ (Responden) & 1063 & 1063 \\
\hline \multirow{3}{*}{ Hasil Belajar } & Koefisien Korelasi & $0,655^{* *}$ & 1.000 \\
\hline & Sig. (2-tailed) & 0,000 & \\
\hline & $\mathrm{N}$ (Responden) & 1063 & 1063 \\
\hline
\end{tabular}

Hasil perhitungan ditunjukkan pada tabel di atas, didapatkan nilai sig. (2-tailed) adalah $(0,000$ $<0,05)$. Artinya terdapat hubungan antara sikap ilmiah dengan hasil belajar siswa pelajaran Biologi di SMA sekabupaten Ogan Komering llir dengan koefisien korelasi sebesar 0.655 yaitu tingkat hubungan kategori "Kuat" dan searah. Jadi dapat disimpulkan bahwa dengan sikap ilmiah siswa yang baik maka hasil belajar Biologi yang diperoleh akan semakin baik dan kebalikannya jika sikap ilmiah siswa kurang baik, maka hasil belajar Biologi yang diperoleh siswa juga akan kurang baik.

\section{Hubungan Sikap IImiah dengan Hasil Belajar}

Berdasarkan hasil jawaban angket sikap ilmiah berjumlah 29 item pertanyaan dan banyaknya jumlah responden sebanyak 1063 siswa dan untuk menarik suatu kesimpulan data dianalisis untuk melihat hubungan kedua variabel tersebut yang ditunjukkan pada Tabel 4.2, diperoleh nilai sig (2-tailed) sebesar $(0,000 \leq 0,05)$. Artinya terdapat hubungan yang signifikan antara sikap ilmiah dengan hasil belajar Biologi siswa SMA sekabupaten Ogan Komering llir dan hasil koefisien korelasi sebesar 0,655 menunjukkan kekuatan hubungan yang kuat antar variabel serta arah koefisien korelasinya adalah positif. Dapat diartikan bahwa terdapat hubungan yang kuat dan searah antara variabel sikap ilmiah dan variabel hasil belajar. Jadi dengan tingginya kemampuan sikap ilmiah siswa maka semakin tinggi pula hasil yang diperoleh siswa, dan sebaliknya dengan rendah kemampuan sikap ilmiah siswa maka hasil belajar Biologi yang diperoleh siswa juga akan rendah.

Data sikap ilmiah tersebut dapat membuktikan bahwa sikap ilmiah menentukan keberhasilan hasil belajar Biologi. Karena sikap ilmiah memberikan pola berpikir terhadap siswa untuk menentukan sikap siswa dalam mempelajari pelajaran yaitu dengan cara seperti berikut ini, siswa akan memberikan tanggapan terkait permasalahan, antusias dalam menemukan sesuatu, dapat menyelesaikan tugas dengan baik, berusaha mempertahankan hasil eksperimen, dapat menyampaikan gagasan dengan baik dan menghargai pemikiran orang lain, serta dapat bekerjasama dengan teman kelompok. Sehingga sikap ilmiah menjadi faktor penentu dalam keberhasilan dan tercapainya hasil belajar yang baik. Sedangkan siswa yang kurangnya sikap positif terhadap pembelajaran dapat menyebabkan rendahnya hasil belajar siswa. Hasil penelitian ini sebelumnya telah dipublikasikan oleh Rozak, Hasanuddin, \& Rusli (2020) menyatakan bahwa terdapat korelasi yang signifikan antara hasil belajar dan sikap ilmiah siswa. Dengan tingginya hasil belajar akan mempengaruhi tingginya sikap ilmiah siswa dan sebaliknya jika hasil belajar Biologi siswa rendah maka sikap ilmiah siswa juga rendah.

Hasil analisis data sikap ilmiah siswa di SMA sekabupaten Ogan Komering llir memiliki rata-rata skor sikap ilmiah sebesar 89 dengan kategori sedang. Sedangkan kemampuan hasil belajar siswa pelajaran Biologi SMA sekabupaten Ogan Komering llir mencapai nilai rata-rata sebesar 82 dengan kategori sedang. Tentunya dengan sikap ilmiah yang sedang akan mempengaruhi hasil bejalar Biologi dengan kategori yang sama yaitu kategori sedang. Hasil penelitian sebelumnya telah dilakukan oleh 
Putri, Irdam \& Yennita (2018:8), menyatakan bahwa; semakin tinggi hasil belajar kognitif siswa maka sikap ilmiah yang didapat akan meningkat dan begitu pula sebaliknya.

Sikap ilmiah siswa menjadi kurang terbentuk dalam kegiatan pembelajaran yang berdampak terhadap pencapaian hasil belajar Biologi siswa, karena selama pandemi Covid-19 Kegiatan belajar di SMA sekabupaten Ogan Komering llir dilakukan secara daring, karena terdapat aturan pemerintah melarang pembelajaran secara tatap muka. Sehingga membuat proses pembelajaran secara daring tidak berjalan dengan optimal. Pembelajaran secara daring memberikan kesulitan terhadap pelajaran Biologi karena pembelajaran secara daring membuat pelaksanaan pembelajaran dengan materi yang perlu adanya praktikum tidak dapat dilakukan. Pembelajaran Biologi adalah suatu pembelajaran yang hakikatnya bertumpu pada kegiatan ilmiah sehingga memberikan suatu pengalaman terhadap peserta didik dalam kegiatan penyelidikan dan memberikan pengalaman secara nyata dalam kehidupan seharihari. Kegiatan pembelajaran dilakukan secara daring melalui aplikasi Whatsapp Groub sebagai alat untuk berdiskusi dan melakukan pengiriman tugas kepada peserta didik.

Kegiatan pembelajaran ini berdampak terhadap keberhasilan belajar siswa. Sehingga kurang menumbuhkan sikap ilmiah peserta didik, karena pembelajaran secara daring mengakibatkan pembelajaran praktikum tidak dapat dilakukan, berdampak terhadap siswa menjadi kurang terlatih untuk melakukan kegiatan ilmiah dengan mencari informasi dan penyelidikan serta menyungkapkan hasil kegiatannya eksperimen. Menurut Arkorful \& Abaidoo (2014), menyatakan bahwa; terdapat beberapa kekurangan dalam pembelajaran online, antara lain: (1) membuat siswa kurang berinteraksi satu sama lain; (2) kurangnya dukungan dalam meningkatkan keterampilan; (3) tidak semua disiplin ilmu dapat menggunakan online secara efektif, misalnya di bidang akademik yang membutuhkan pengalaman langsung (ilmiah), pembelajaran online mungkin lebih sulit.

Pembelajaran secara daring guru hanya fokus terhadap penyampaian konsep materi pembelajaran melalui Whatsapp Groub sehingga siswa tidak terlatih untuk memiliki sikap ilmiah dalam belajar sains yang akan mempengaruhi keberhasilan hasil belajar siswa. Menurut Magdalena, Sari, Hurrahmah, \& Sari (2020) menyatakan bahwa; sikap ilmiah adalah faktor yang dapat menentukan keberhasilan hasil belajar siswa. Hal ini dikuatkan oleh pendapat Djaali (2015) menyatakan; sikap belajar yang positif erat kaitannya antara motivasi dengan minat siswa dalam belajar, dengan memiliki sikap positif terhadap pembelajaran menjadikan siswa akan menyenangi pelajaran dan lebih giat belajar sehingga memotivasi siswa untuk mencapai hasil belajar dengan baik. Hal tersebut berbeda dengan siswa yang memiliki sikap negatif terhadap pembelajaran akan mudah putus asa dan menjadi malas dan ceroboh untuk melakukan kegiatan ekperimen sehingga menjadikan keberhasilan belajar menurun.

Pendapat tersebut diperkuat oleh penelitian Wulandari \& Febriana (2020), dengan hasil penelitian adalah adanya hubungan antara sikap siswa dengan hasil belajar yang telah diperoleh oleh siswa". Sehingga sangat penting menumbuhkan sikap ilmiah dengan cara memiliki rasa keingintahuan yang tinggi mengenai pelajaran sehingga siswa antusias untuk mengajukan pertanyaan dan mencari jawaban, membiasakan sikap jujur, memiliki sikap tekun, sikap objektif, sikap kerterbukaan, sikap teliti dan sikap tanggung jawab. Dengan siswa memiliki sikap pada indikator sikap ilmiah tersebut dapat menentukan keberhasilan belajar peserta didik. Pendapat tersebut sejalan dengan penelitian Azmi, Rahayu, \& Hikmawati, 2016) berkata bahwa; di dalam sikap ilmiah terdapat indikator yang berpengaruh sangat besar terhadap hasil belajar, yaitu: semangat menemukan jawaban, jujur terhadap data, menghargai gagasan teman, dan bekerjasama dengan teman, teliti dan bertanggung jawab, dll. Dari semua sikap tersebut dilakukan selama proses pembelajaran untuk memberikan pelatihan dan 
pembiasaan terhadap pemecahan masalah. Semua sikap yang baik tersebut sangat berpengaruh positif terhadap hasil aktivitas belajar siswa.

Pengukuran sikap ilmiah sangat penting dalam pembelajaran Biologi terutama bagi siswa untuk menentukan sikap siswa dalam belajar secara ilmiah, sehingga memberikan perasaan suka terhadap kegiatan ilmiah dan terlatih dalam menyelesaikan masalah sehingga dapat memotivasi diri untuk mencapai hasil belajar dan manfaat untuk guru adalah dengan mengetahui sikap ilmiah siswa dapat menerapkan strategi atau model pembelajaran yang dapat meningkatkan kemampuan sikap ilmiah siswa dan dapat menciptakan suasana belajar yang nyaman dan membangkitkan antusias siswa serta menjadikan siswa kreatif. Sehingga siswa dengan mudah mencapai tujuan pembelajaran dan hasil belajar yang diharapkan. Untuk menunjang penguasaan sikap ilmiah maka perluhnya penanaman sikap ilmiah terhadap siswa terutama dalam pembelajaran Biologi yang mengharuskan siswa bersikap ilmiah dan sistematis.

\section{SIMPULAN}

Berdasarkan hasil analisis deskripsi sikap ilmiah siswa SMA sekabupaten Ogan Komering diperoleh skor rata-rata keseluruhan sebesar 89 dengan kategori sedang sedangkan hasil belajar Biologi siswa rata-rata skor sebesar 82 dengan kategori sedang. Hasil uji spearmen's rho mendapat nilai Sig. (2-tailed) sebesar $(0,000 \leq 0,05)$. Artinya terdapat korelasi signifikan dan searah antara sikap ilmiah dengan hasil belajar pelajaran Biologi, dengan kekuatan hubungan sebesar 0,655 yaitu tergolong kuat. Oleh karena itu, ditarik kesimpulan bahwa kemampuan sikap ilmiah siswa yang baik akan menentukan hasil belajar yang baik pula, dan sebaliknya, kemampuan sikap ilmiah siswa yang kurang baik akan menentukan hasil belajar yang kurang baik pula.

\section{UCAPAN TERIMA KASIH}

Ucapakan banyak terimakasih oleh peneliti kepada para dosen pembimbing dan penguji yang selama ini telah banyak memberi arahan dan bimbingan dalam penyusunan karya ilmiah. Serta menyucapkan terimakasih kepada almamater hijauku universitas muhammadiyah Palembang serta rekan seperjuangan yang telah banyak memberikan dukungan terhadap penelitian ini.

\section{RUJUKAN}

Arifin, Z. (2014). Evaluasi Pembelajaran . Bandung: Rosdakarya.

Arkorful, V., \& Abaidoo, N. (2014). The role of e-learning, the advantages and disadvantages of its Adoption in Higher Education. International Journal of Education and Research, 2(12), 397-410.

Azmi, M. K., Rahayu, S., \& Hikmawati. (2016). Pengaruh Model Problem Based Learning dengan Metode Eksperimen dan Diskusi Terhadap Hasil Belajar Fisika Ditinjau dari Sikap IImiah Siswa Kelas X MIPA SMA N 1 Mataram. Jurnal Pendidikan Fisika dan Teknologi, 2(2), 86-94.

Azwar, S. (2012). Reliabelitas dan Validitas. Yogyakarta: Pustaka Pelajar.

Dewi, D., \& Rosana, D. (2017). Pengembangan Instrumen Penilaian Kinerja. Jurnal Kependidikan, 1(1), 67-83.

Djaali. (2015). Psikologi Pendidikan . Jakarta: Bumi Aksara. 
Haryaka, U., \& Haslidia. (2019). Pengaruh Konsep Diri, Minat dan Sikap IImiah Siswa. PRISMA, Prosiding Seminar Nasional Matematika. 2, hal. 737-747. SEMARANG: universitas Negeri Semarang.

Jhon, O. K., \& Ademola, O. R. (2014). Scientific Attitude, Attitude to Science and Science Achievement of Senior Secondary. Journal of Educational and Social Research, 4(1), 445-452.

Khairunnisa, Ita, \& Istiqamah. (2019). Keterampilan Proses Sains (KPS) Mahasiswa Tadris Biologi pada. Jurnal Biologi-Inovasi Pendidikan, 1(2), 58-65.

Magdalena, I., Sari, D. M., Hurrahmah, M., \& Sari, N. R. (2020). Pengembangan Instrumen Penilaian Sikap IImiah Pada Pembelajaran Dengan Model Latihan Penelitian di SDN Rawakidang. Jurnal Edukasi dan Sains, 2(3), 350-359.

Putri, A., Idrus, I., \& Yennita. (2017). Analisis Korelasi Sikap IImiah dan Hasil Belajar Kognitif Siswa. Diklabio: Jurnal Pendidikan dan Pembelajaran Biologi, 1(1), 1-9.

Rozak, A., Hasanuddin, \& Rusli, M. A. (2020). Hubungan Sikap Ilmiah dengan Hasil Belajar Ipa Peserta Didik Kelas VIII SMP Negeri 33 Makassar. Jurnal IPA Terpadu, 4(1), 52-62.

Sihombing, C. (2016). Hubungan Keterampilan Metakognitif dan Sikap IImiah. Jurnal IImiah "Dunia IImu", 2(1), 96-107.

Siregar, S. (2015). Statistika Terapan Perguruan Tinggi. Jakarta: Kencana .

Supardi, R., Istiyono, E., \& Setilalaksana, W. (2019). Developing Scientific Attitudes Instrument of Students in Chemistry. International Seminar on Science Education (1-5). Yogyakarta: IOPSCIENCE.

Wulandari, M., \& Febriana, N. Y. (2020). Analisis Hubungan Sikap dengan Hasil Belajar Siswa di SMA Negeri 1 Sungai Penuh. Jurnal Pendidikan MIPA, 10(2), 122-128. 